\title{
Tetraconazole-induced Programmed Cell Death in Schizosaccharomyces pombe
}

\section{Schizosaccharomyces pombe'deTetrakonazol Kaynaklı Programlı Hücre Ölümü}

\author{
Hızlan Hıncal Ağuş ${ }^{*}$, Ahsen Çetin ${ }^{2}$, İrem Naz Yalçın ${ }^{3}$
}

Geliş / Received: 08/07/2021

Revize / Revised: 10/09/2021

Kabul / Accepted: 14/09/2021

\begin{abstract}
Tetraconazole, a systemic triazole fungicide, shows potential toxic effects in agriculture and human health. Therefore, its cytotoxic effects and accompanying mechanisms should be unraveled. S. pombe (ED666) was used in this study, as a unicellular biology and toxicology model. Cells were grown on standard media and all treatments were done at $30{ }^{\circ} \mathrm{C}$ and shaking at $180 \mathrm{rpm} 1-10 \mathrm{mg} / \mathrm{L}$ tetraconazole induced a dose-dependent cell death. Apoptosis was monitored by DAPI ve AO/EB staining. Excessive ROS production and mitochondrial impairment were shown by DCFDA/NBT assays and Rhodamine 123 staining, which were supported by increased expressions of superoxide dismutases and glutathione peroxidase. Involvement of one of the potential apoptotic genes, Cnxl, in apoptosis was shown by increased transcription whereas two other potential genes, Pcal and Aifl, were not affected by tetraconazole treatment. In conclusion, tetraconazole-induced cytotoxicity and underlying mechanisms which were mediated via ROS damage and mitochondrial dysregulation (Cnxl-driven) were clarified in S. pombe.
\end{abstract}

Keywords- Schizosaccharomyces Pombe, Tetraconazole, Apoptosis, Cnxl, Oxidative Damage

$\overline{\mathbf{o ̈ Z}}$

Sistemik triazol bir fungisit olan tetrakonazol tarımda ve insan sağlığında potansiyel toksik etkiler göstermektedir. Bu yüzden, sitotoksik etkileri ve eşlik eden mekanizmaları açığa çıkarılmalıdır. Bu çalışmada, tek hücreli biyoloji ve toksikoloji modeli olarak $S$. pombe (ED666) kullanılmıştır. Hücreler standart medyumda büyütülmüş, muameleler $30{ }^{\circ} \mathrm{C}$ 'de ve $180 \mathrm{rpm}$ hızda çalkalamalı olarak yapılmıştır. 1-10 mg/L tetrakonazol doz-bağımlı hücre ölümüne sebep olmuştur. Apoptoz DAPI ve AO/EB boyamasıyla görüntülenmiştir. Aşırı ROS üretimi ve mitokondriyel bozulma DCFDA/NBT deneyleri ve Rhodamin 123 boyamasıyla gösterilmiş, bu sonuçlar da süperoksitdismutazlar ve glutatyonperoksidaz ifadelerindeki artışlarla desteklenmiştir. Potansiyel apoptotik genlerden biri olan $\mathrm{Cnx} 1$ 'in apoptozla ilişkisi transkripsiyonundaki artışla gösterilirken, diğer iki potansiyel gen, Pca1 ve Aifl tetrakonazolden etkilenmemiştir. Sonuç olarak, tetrakonazol kaynaklı apoptoz ile, ROS hasarı ve mitokondriyel düzensizliğin (Cnxl-yoluyla) aracılık etmiş olduğu mekanizmalar S. pombe'de açıklığa kavuşturulmuştur.

Anahtar Kelimeler-Schizosaccharomyces Pombe, Tetrakonazol, Apoptoz, Cnx1, Oksidatif Hasar

1*Sorumlu yazar iletişim: hizlanhincal.agus@yeniyuzyil.edu.tr (https://orcid.org/0000-0002-0252-9501)

Moleküler Biyoloji ve Genetik Bölümü, İstanbul Yeni Yüzyıl, Üniversitesi, İstanbul

2İletişim: ahsen.cetin@yeniyuzyil.edu.tr (https://orcid.org/0000-0001-5341-3456)

Moleküler Biyoloji ve Genetik Bölümü, İstanbul Yeni Yüzyıl, Üniversitesi, İstanbul

3Iletişim: iremyalcin11298@gmail.com (https://orcid.org/0000-0002-4483-1610)

Moleküler Biyoloji ve Genetik Bölümü, İstanbul Yeni Yüzyıl, Üniversitesi, İstanbul 


\section{INTRODUCTION}

Azoles are antifungal agents showing variation in activity, toxicity, and interaction potential [1]. While some azoles can potentially inhibit oxidative drug-metabolizing enzyme systems [2-4], others were shown to interact with transporter proteins [5]. Among azole antifungal agents, tetraconazole is a systemic triazole fungicide, which is formed by a chiral carbon atom and two enantiomers and is widely used as an eradicant and protectant against fungal infections [6,7]. Although little is known on the potentially toxic effects of tetraconazole in human health, researchers have identified its inhibitory effects related to its high affinity for fungal demethylases, particularly for fungal P450 enzymes [8-10] having roles in ergosterol biosynthesis in cell membranes [11].

The median lethal dose $\left(\mathrm{LD}_{50}\right)$ for tetraconazole was calculated as $1,030 \mathrm{mg} / \mathrm{kg}$ in rats [12], whereas 7 pentoxyresorufin O-depenthylase values were dramatically elevated [13]. Hepatocyte necrosis and inflammation along with benign and malignant liver cell tumors, bodyweight loss, a decrease of plasma glucose, and increased levels of blood nitrogen and alkaline phosphatase were found in rats received 640-2500 ppm tetraconazole [14]. In addition, moderate-to-severe inhibition of cell viability and proliferation in Chinese hamster ovary cell line (CHO) was reported when the cells were treated with tetraconazole for $72 \mathrm{~h}$ (the calculated $\% \mathrm{C} 1 / 2-50 \%$ decrease in cell density- was $39.2 \mu \mathrm{M})$ and/or with other azoles such as tebuconazole $(\% \mathrm{C} 1 / 2: 98.1 \mu \mathrm{M})$ and propiconazole $(\% \mathrm{C} 1 / 2: 44.0 \mu \mathrm{M})[15]$. Besides, tetraconazole was considered highly toxic to fish and other aquatic organisms in which $96 \mathrm{~h}$ the lethal concentration $50\left(\mathrm{LC}_{50}\right)$ values were calculated between $2.5-4.3 \mathrm{mg} / \mathrm{L}$ in fish. Given the significance of azoles in the pharma industry, chemical industry, and medicine, possible cytotoxic, genotoxic, inhibitor, carcinogenic, and/or anti-cancer potentials are to be investigated. The study for anti-cancer potentials mainly focused on azole and triazole derivatives, such as 1, 2, 4-triazoles [16], ribavirin [17], and DAN94 [18]. On the other hand, there are a lot of research focused on azoles-fungi interactions. Candida species, which are well-known pathogenic fungi class, showed a range of minimum inhibitory concentration (MIC: $0.03-128 \mu \mathrm{g} / \mathrm{mL}$ ) when a variety of azoles (fluconazole, itraconazole, voriconazole, amphotericin B, tetraconazole and tebuconazole) were administered [19]. As genetic tools and its manupilation is limited in pathogenic fungi, Saccharomyces cerevisiae, which was known to have ScErg5 gene (the target of azoles), was used to monitor cellular metabolism of antifungal drugs, particularly azoles and derivatives [20]. 19-104 $\mu \mathrm{M}$ MICs were reported when general antifungal azoles, fluconazole and miconazole, were administered to $S$. cerevisiae [21]. However, a complete understanding of azoles, in particular, tetraconazole toxicity, and regulation of cell death in the fission yeast (Schizosaccharomyces pombe), which has many advantages and is more similar to higher eukaryotes in some issues, are currently unknown and waiting to be explained.

Analogous cell cycle control [22], mitochondrial biogenesis [23], and programmed cell death subroutines [24-26], in addition, a small genome that can be easily manipulated [27] present Schizosaccharomyces pombe as a well-established model cell for molecular toxicology, cell biology and biochemistry studies [28,29]. Besides, the Warburg effect, which refers to the reprogrammed energy metabolism in cancer cells, resembling the energy metabolism of highly proliferative yeast cells, constitutes a valuable opportunity in cancer research [30-32]. Consequently, the underlying mechanisms for cancer therapeutic candidates can be understood by using fission yeast as a eukaryotic unicellular cell death model [33-35].

There are several programmed cell death subroutines were found in the fission yeast: Apoptosis, necroptosis, and autophagy. Numerous research focused on fission yeast apoptosis and necrosis. However, cellular physiology of yeast apoptosis is not fully understood and waiting to be unraveled [36]. Whereas oxidative stress [25], mitochondrial impairment and lipotoxicity are well-known stimulations for the positive regulation of apoptosis in yeast, we do not know much about the dark side of the genetic regulation[37]. Indeed, many genes (caspases and endonucleases) having potential roles in apoptosis of Baker's yeast (S. cerevisiae) were investigated [38], however, the orthologous genes (at least several of them) in the fission yeast (S. pombe)are waiting to be enlightened.

This study aims to evaluate the cytotoxicity of tetraconazole and its mechanism and to show the potential of S. pombe for cell biology, toxicology, and cancer research. Mortality, proliferation, and apoptosis along with candidate genes for apoptosis were assessed. Besides, oxidative stress, DNA damage, and mitochondrial damage were evaluated as accounting mechanisms. This study contributes to literature for tetraconazole toxicity and evaluation of its medicinal potential. 


\begin{tabular}{|c|c|c|}
\hline & $\begin{array}{l}\text { BŞEÜ Fen Bilimleri Dergisi } \\
8(2), 833-843,2021\end{array}$ & $\begin{array}{r}\text { BSEU Journal of Science } \\
\text { https://doi.org/10.35193/bseufbd.963547 }\end{array}$ \\
\hline & & 2458-7575 (https://dergipark.org.tr/tr/pub/bseufbd) \\
\hline
\end{tabular}

\section{MATERIALS AND METHODS}

\section{A. Reagents}

Media components,methylene blue,arsenic(III) oxide, hydrogen peroxide, DCFDA, Rhodamine 123, NBT, and DAPI were purchased from Sigma (Istanbul, Turkey).Tetraconazole (dichlorophenyl)tetrafluoroethoxy)propyl]-1,2,4-triazole) was a kind gift from E. Yoruk (Istanbul Yeni Yuzyil University) (Sigma, U.S.A.).

\section{B. Yeast, Media, and Growth Conditions}

S. pombewild-type strain ED666wasa kind gift from B. Palabiyik (Istanbul University). Yeast was grown in YEL media containing yeast extract and glucose on a shaker at $150 \mathrm{rpm}$. at $30{ }^{\circ} \mathrm{C}$ in all experiments. $1 \times 10^{6}$ cells $/ \mathrm{ml}$ cultures were used for experiments.

\section{Tetraconazole Exposure and Cytotoxicity}

Yeast culture $\left(\mathrm{OD}_{600} \approx 1\right.$, in YEL media) from overnight incubation $(16 \mathrm{~h})$ were counted using Carl-Zeiss, Axio Observer 3 microscopefollowed by adjusting to $1 \times 10^{6}$ cells $/ \mathrm{ml}$ in conical flasks. Tetraconazole (TCN) solution was prepared in ethanol. Cells were exposed to different concentrations of tetraconazole $(0-10 \mathrm{mg} / \mathrm{L}$ in ethanol) and solvent controlfor $24 \mathrm{~h}$. Arsenic(III) oxide was positive control of apoptosis[39]. Hemocytometer was used for the evaluation of relative cell proliferation. Cells were prepared in PBS and were stained with methylene blue. Cells were observed under a light microscope from 200-250 cells in each biological replicate ( $\mathrm{n}=5)$.

\section{D.Detection of Apoptosis by AO/EB and DAPI staining}

$1 \mu \mathrm{g} / \mathrm{ml}$ DAPI was used to monitor the cell nucleus as previously reported[40]. Carl-Zeiss, Axio Observer 3 fluorescent microscope( $63 \mathrm{x}$ objectives) was used to observe cells at $358 \mathrm{~nm}$ and $461 \mathrm{~nm}$. Besides, yeast was stained using AO/EB as previously described [38,39] and examined under Carl-Zeiss, Axio Observer 3 using 63x objectives at $500 \mathrm{~nm}$ and530 nm for $\mathrm{AO}$ (acridine orange), and $510 \mathrm{~nm}$ and $595 \mathrm{~nm}$ for EB (ethidium bromide).

\section{E. ROS detection by DCFDA staining and NBT assay}

ROS levels were measured using DCFDA as declared previously [25,43] and examined under Carl-Zeiss, Axio Observer 3 fluorescent microscope(63x objectives) at $495 \mathrm{~nm}$ and529 nm. NBT reduction experiment was done as described previously [43]. NBT was used at a concentration of $0.1 \%$ and cells were incubated for 1 hour at $1 \times 10^{6}$ cells $/ \mathrm{ml}$ concentration. Cells were washed and fixed using absolute methanol and diluted methanol $(70 \%)$. $2 \mathrm{M} \mathrm{KOH}$ and DMSO were used to solubilize the dry pellet. The optical density of the final solution was calculated by microplate spectrophotometer(Thermo Scientific, Multiskan Go) at $620 \mathrm{~nm}$.

\section{F.Detection of MTP by Rhodamine 123 assay}

Rhodamine 123was used to stain mitochondria as indicated previously[44]. The reaction was performed in sodium citrate buffer containing glucose and rhodamine. Incubation was $15 \mathrm{~min}$ at room temperature. Cells were visualized by Carl-Zeiss, Axio Observer 3 fluorescent microscope(63x objectives) at $505 \mathrm{~nm}$ and $534 \mathrm{~nm}$.

\section{G.RNA Extraction and RT-PCR}

Alteration in mRNA levels for Sod1, Sod2, GPxl,and pro-apoptotic genes was given in ESI. $\dagger$ Oligonucleotides were designed using Primer3Plus and given in Table $\mathrm{S} 1 \uparrow$.

\section{H. Statistical analysis}

Experimental data were shown as mean \pm standard error of the mean (SEM). One-way ANOVA and Tukey's tests (Graphpad, USA) were used to understand the statistical difference. 


\begin{tabular}{|c|c|c|}
\hline & $\begin{array}{l}\text { BŞEÜ Fen Bilimleri Dergisi } \\
8(2), 833-843,2021\end{array}$ & $\begin{array}{r}\text { BSEU Journal of Science } \\
\text { https://doi.org/10.35193/bseufbd.963547 }\end{array}$ \\
\hline $\begin{array}{l}\text { BILECIK SEYH EDEBALL } \\
\text { ONIVERSITES }\end{array}$ & & 2458-7575 (https://dergipark.org.tr/tr/pub/bseufbd) \\
\hline
\end{tabular}

\section{RESULTS}

\section{A. Tetraconazole-Induced Cytotoxicity is Dose-dependent}

Tetraconazole was previously shown to induce cell death in fungi [45]. We hypothesized that tetraconazole-induced cell death in our model fungi $S$. pombe was related tothe apoptotic activity of this triazole. To test this hypothesis, we first analyzed cell growth using a hemocytometer, which was significantly inhibited $(p<0.01)$ after tetraconazole exposure between $2-20 \mathrm{mg} / \mathrm{L}$ (Figure 1A), whereas mortality notably and gradually increased $(p<0.01)$, which was evaluated using methylene blue assay. Methylene blue permeates dead cell membranes and stains cytoplasm and nucleus, in contrast, live cells having intact cell membranes are capable of blocking permeation. The calculated the half-maximum inhibitory concentration( $\left(\mathrm{IC}_{50}\right)$ value was $7.03 \mathrm{mg} / \mathrm{L}$.
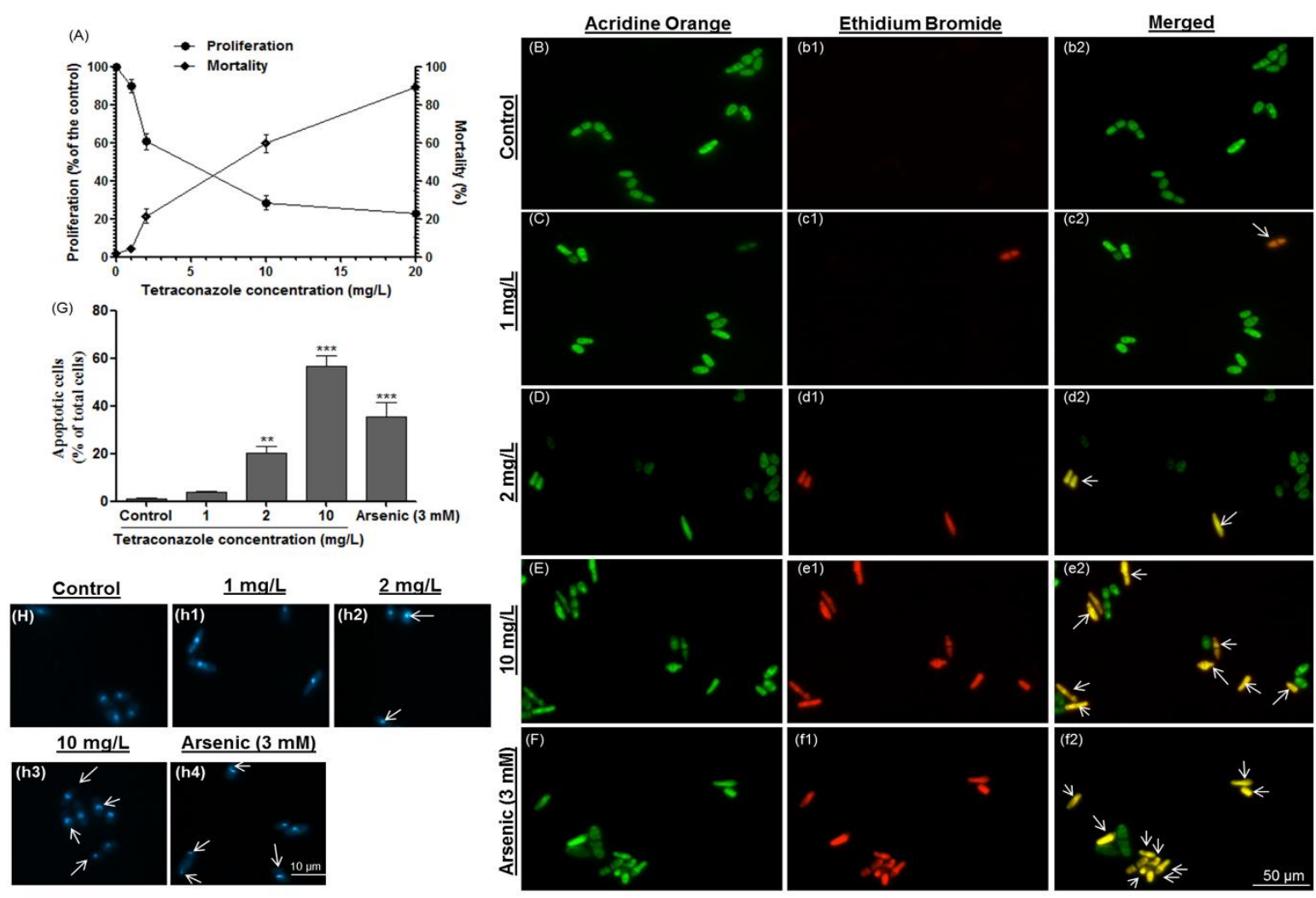

Figure 1. Cell proliferation, viability, apoptosis, and nuclear morphology after exposure to tetraconazole solutions for $24 \mathrm{~h}$ : A. Cell proliferation and mortality were assessed by hemocytometer and by methylene blue assay in comparison to ethanol (solvent) control $(0 \mathrm{mg} / \mathrm{L}$ refers to solvent control). Solvent control includes $0.05 \%$ ethanol. B-F. Viable and dead cells were shown via fluorescent microscope after treatment with $1-10 \mathrm{mg} / \mathrm{L}$ tetraconazole and arsenic. Arsenic(III) was apoptosis-positive control. Arrows indicate apoptotic yeast. G. The graph shows the percentage of apoptosis in yeast treated with $0-10 \mathrm{mg} / \mathrm{L}$ tetraconazole and arsenic $(\mathrm{n}=5)$. Asterisks were used to show significantly different values $(* * \mathrm{p}<0.01, * * * \mathrm{p}<0.001)$. H. DAPI assay was performed after treatment with $1-10 \mathrm{mg} / \mathrm{L}$ tetraconazole and arsenic. Arrows: Anucleation or fragmentation.

\section{B. Cell Death is Dependent on Apoptosis}

We observed apoptotic cells (Figure 1B-F) by using AO/EB assay showing both dead and live cell membranes along with cell nuclei. Ethidium bromide stains only the dead cell nucleus, whereas acridine orange penetrates both live and dead cells and stains the nucleus. While regular green nucleus is showing live cell, fragmented orange-bright or red nucleus is indicating apoptotic cell. Cells were exposed to tetraconazole at 1, 2, and $10 \mathrm{mg} / \mathrm{L}$ doses for $24 \mathrm{~h}$. Apoptotic cells were marked by arrows in Figure 1B-F. Number of apoptotic cells was significantly different in $2 \mathrm{mg} / \mathrm{Land} 10 \mathrm{mg} / \mathrm{L}$ tetraconazole groups $(p<0.01$ and $p<0.001)$ as illustrated in Figure 1G. Apoptosis dramatically increased at 2 and $10 \mathrm{mg} / \mathrm{L}$ doses (\%20.21 and \%56.79) compared to the control group 


\begin{tabular}{|c|c|c|}
\hline & $\begin{array}{l}\text { BŞEÜ Fen Bilimleri Dergisi } \\
8(2), 833-843,2021\end{array}$ & $\begin{array}{r}\text { BSEU Journal of Science } \\
\text { https://doi.org/10.35193/bseufbd.963547 }\end{array}$ \\
\hline $\begin{array}{l}\text { BILECIK SEYH EDEBALL } \\
\text { ONIVERSITES }\end{array}$ & & 2458-7575 (https://dergipark.org.tr/tr/pub/bseufbd) \\
\hline
\end{tabular}

(\%1.16). The percentages of apoptotic cells were comparable with mortality rates $(\% 21.57$ and \%59.60) at 2 and $10 \mathrm{mg} / \mathrm{L}$ doses.

In addition, apoptosis was confirmed by DAPI staining. After the exposure period, cells were fixed with formaldehyde. When cells were stained with DAPI, we observed nuclear fragmentation, condensed, crescent- and dot-shaped cell nuclei, which were known as typical apoptotic markers [46, 47], at 2-10 mg/L doses and in arsenic control (apoptosis control) cells (Figure 1H, h1: $1 \mathrm{mg} / \mathrm{L} ; \mathrm{h} 2: 2 \mathrm{mg} / \mathrm{L} ; \mathrm{h} 3: 10 \mathrm{mg} / \mathrm{L} ; \mathrm{h} 4: 3 \mathrm{mM}$ arsenic trioxide).

\section{C.Tetraconazole-Induced ROS Production Potentially Activated Apoptosis}

DCFDA immediately reacts with ROS, mostly superoxide anions, and transforms to its oxidized fluorescent form (DCF) after permeation to the membrane and localization to the cytoplasm. As demonstrated in Figure 2, green fluorescence gradually increased in the experimental group at all concentrations of tetraconazole and in hydrogen peroxide control. In addition, using NBT reduction assay, levels of reactive oxygen species were measured and calculated as percentages of the control group. NBT reduction reflects ROS generation [48]. As shown in Figure 2F, NBT reduction significantly increased (2-5-fold) at all dose groups $(p<0.05$ for $1 \mathrm{mg} / \mathrm{L}, p<$ 0.01 for $2 \mathrm{mg} / \mathrm{L}$ and $10 \mathrm{mg} / \mathrm{L}$ tetraconazole concentrations, which was consistent with increase in mortality (\%21.57 and \%59.60; see Figure 1A) and apoptosis (\%20.21 and \%56.79; see Figure 1G). As illustrated in Figure 2G-I, Sod1 and GPXI mRNA levels increased 1.5-2-fold at all concentrations of tetraconazole, whereas Sod2 mRNA levels remained unchanged except at $2 \mathrm{mg} / \mathrm{L}$ tetraconazole concentration. Positive regulation of the antioxidant enzyme system generally indicates excessive reactive oxygen species production [49], which means that organism is to recover antioxidant enzymes exhausted by superoxide and other oxidizing molecules [50].
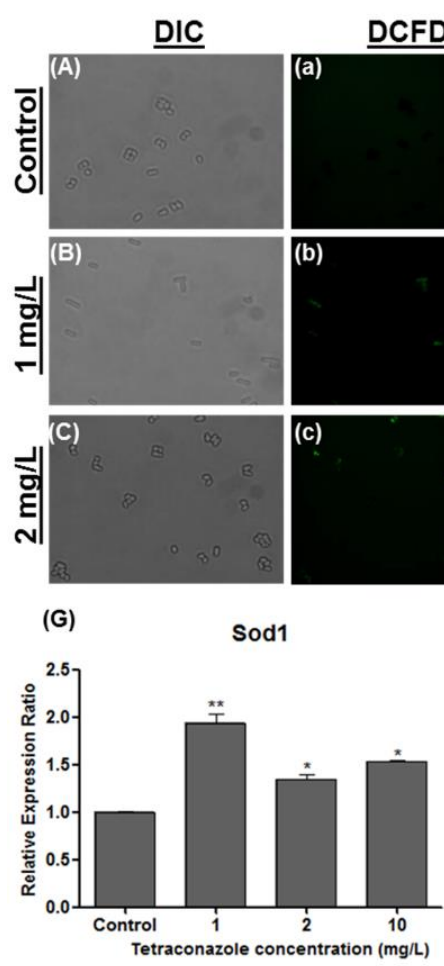

DCFDA
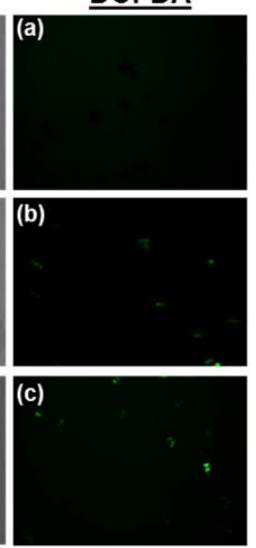

(H)

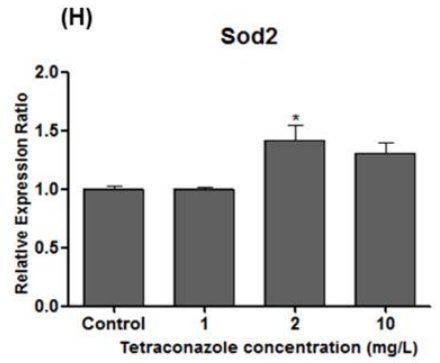

DCFDA
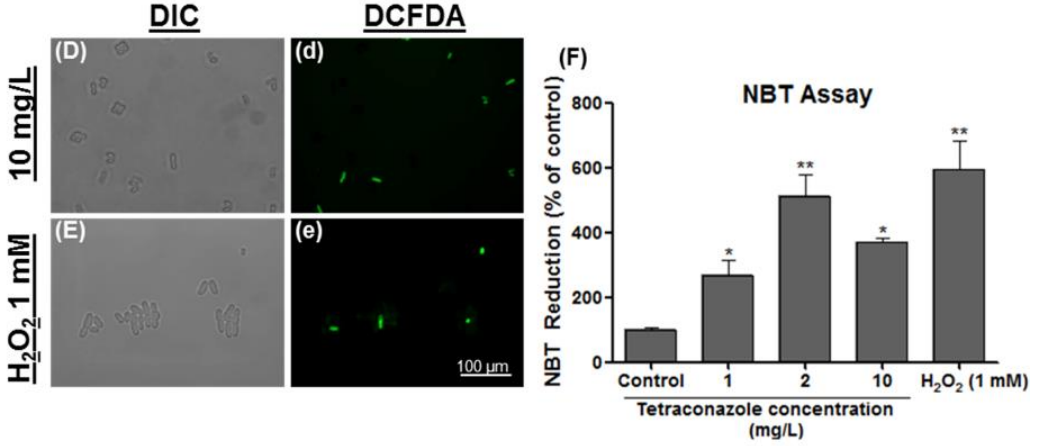

Figure 2. ROS levels and antioxidant gene expression: A-E. ROS generation in yeast treated with $1-10 \mathrm{mg} / \mathrm{L}$ tetraconazole and $1 \mathrm{mM}$ hydrogen peroxide were visualized and calculated using a fluorescence microscope. F. ROS production in yeast treated with $0-10 \mathrm{mg} / \mathrm{L}$ tetraconazole and $1 \mathrm{mM}$ hydrogen peroxide was also measured by NBT assay. ROS production was determined at $620 \mathrm{~nm}$ and given as a percentage of a control group. G-I. Sod1 (G), Sod2 (H), and Gpx1 (I) expressions were analyzed using RT-PCR. Significance is marked by asterisks $(* p<0.05, * * p<0.01 ; \mathrm{n}=3)$. 


\begin{tabular}{|c|c|c|}
\hline & $\begin{array}{l}\text { BŞEÜ Fen Bilimleri Dergisi } \\
8(2), 833-843,2021\end{array}$ & $\begin{array}{r}\text { BSEU Journal of Science } \\
\text { https://doi.org/10.35193/bseufbd.963547 }\end{array}$ \\
\hline $\begin{array}{l}\text { BLLCEKSEEYHEDEBALI } \\
\text { UNIVERSITESS }\end{array}$ & & 2458-7575 (https://dergipark.org.tr/tr/pub/bseufbd) \\
\hline
\end{tabular}

\section{Loss of MTP Elucidate the Effect of Tetraconazole on Mitochondria}

Disruption of mitochondria is an early apoptotic marker, which can be measured as transmembrane potential $(\Delta \Psi \mathrm{m})$ [51]. Loss of MTP was monitored using mitochondrial fluorescence stain Rhodamine 123. Active mitochondrion sequesters fluorescence stain via the activity of intact membrane pumps and emits green fluorescence, whereas apoptotic mitochondrion cannot pump the dye to the matrix, therefore the dye cannot fluoresce. The difference in fluorescence intensity of experimental and control groups was demonstrated in Figure 3. A dramatic decrease in fluorescence intensity was calculated at all dose groups. Intensities weredramaticallylowered 2-3-fold at $1-10 \mathrm{mg} / \mathrm{L}$ tetraconazole concentrations $(p<0.001)$ as well as in arsenic control (see Figure 7F).

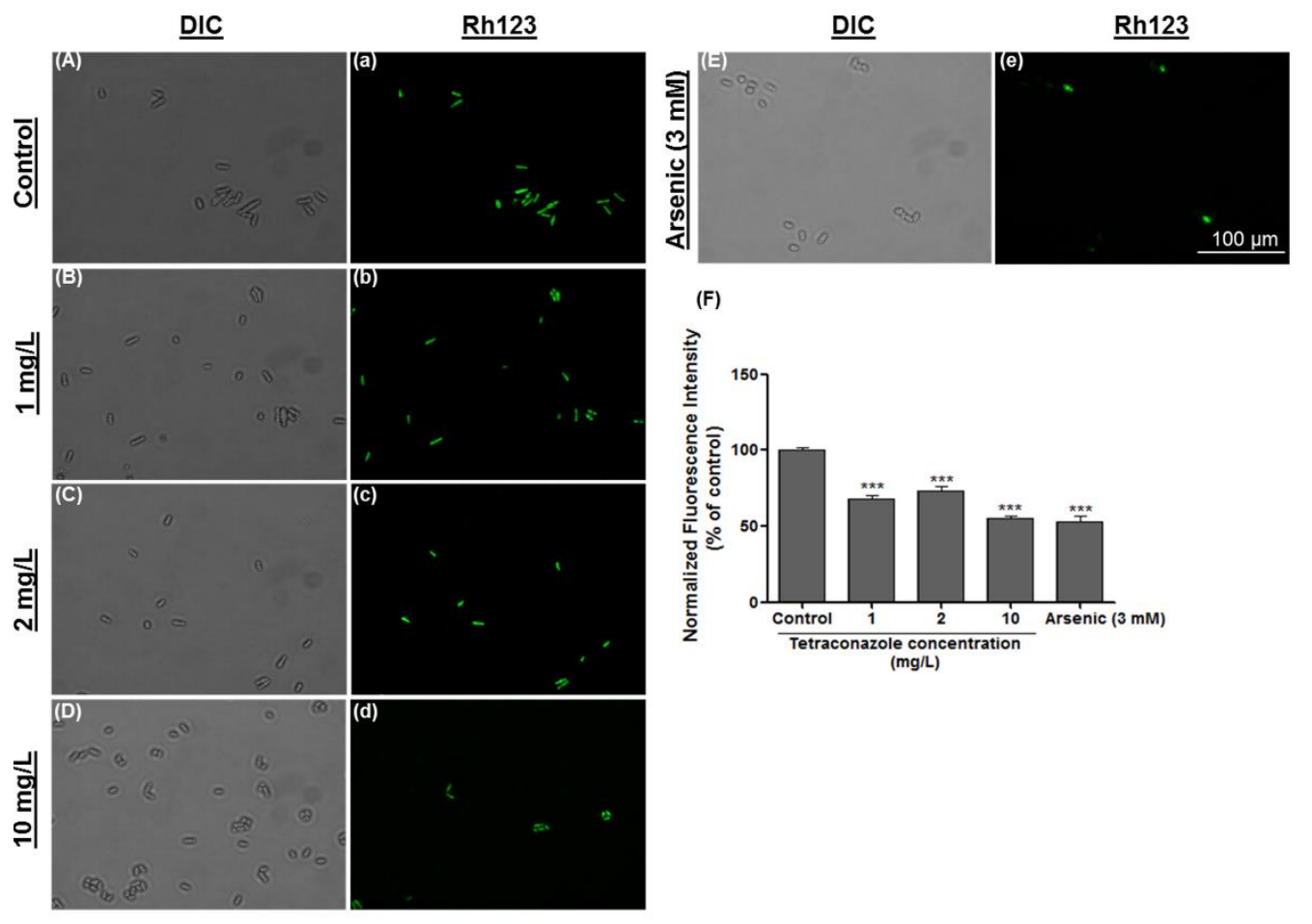

Figure 3. Mitochondrial transmembrane potential (MTP) was demonstrated by Rhodamine 123 staining: A-E. MTPs treated with 1-10 $\mathrm{mg} / \mathrm{L}$ tetraconazole and arsenic were visualized and measured. F. Decrease of fluorescent intensity in the cells treated with tetraconazole $(0-$ $10 \mathrm{mg} / \mathrm{L})$ was measured and expressed as a percentage of a control group. Significance was indicated by asterisks $(* * * \mathrm{p}<0.001 ; \mathrm{n}=3)$.

\section{E. Candidate apoptosis-related genes showed different expressions}

Pcal, Cnxl, and Aifl were reported to regulate and progressthe apoptotic process in S. pombe[53-55]. Although the function of Pcal is currently not clear, we showed 2-fold decrease $(p<0.05)$ in Pcalexpression at 10 $\mathrm{mg} / \mathrm{L}$ tetraconazole group ( $p<0.05$, Figure 4). Another pro-apoptotic gene, Cnxl (Calnexin-1), which was previously reported to regulate ER-stress-induced cell death [53], was found transcriptionally activated (1.5-2fold, $p<0.05)$ in response to tetraconazole exposure in this study. However, Aifl, a FAD-dependent flavoenzyme homologous to mammalian Aifl, which is known to activate chromatin condensation and other apoptosis-related processes after its release from mitochondria [56], remained unchanged $(p>0.05)$ after tetraconazole exposure. 


\begin{tabular}{|c|c|c|}
\hline & $\begin{array}{l}\text { BŞEÜ Fen Bilimleri Dergisi } \\
8(2), 833-843,2021\end{array}$ & $\begin{array}{r}\text { BSEU Journal of Science } \\
\text { https://doi.org/10.35193/bseufbd.963547 }\end{array}$ \\
\hline $\begin{array}{l}\text { BILECIK SEYH EDEBALL } \\
\text { ONIVERSITES }\end{array}$ & & 2458-7575 (https://dergipark.org.tr/tr/pub/bseufbd) \\
\hline
\end{tabular}
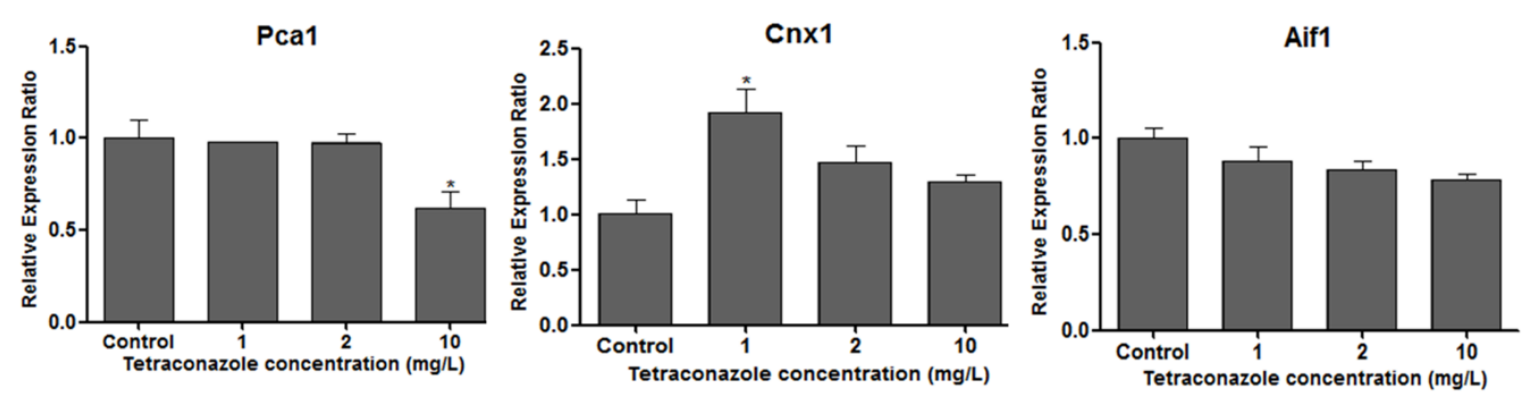

Figure 4. Gene expressions of pro-apoptotic genes in S. pombe treated with 0-10 mg/L tetraconazole: Pca1, Cnx1, and Aif1 mRNA levels were shown using RT-PCR. Significance is shown by asterisks $\left({ }^{*} p<0.05 ; \mathrm{n}=3\right)$.

\section{DISCUSSION}

In S. pombe, programmed cell death subroutines occur inseveral ways including apoptosis, autophagy, and necrosis, which are highly responsive to chemical and physical stressors, such as drugs, plant-originated chemicals, heat, and starvation [57]. In our research, fission yeast responded to tetraconazole, an azole derivative thatis used as an antifungal agent, and cell proliferation and viability gradually decreased in a dose-dependent manner. Although limited data is known on tetraconazole toxicity, generally azoles are defined as N-demethylase inhibitors that can subsequently inhibit cell membrane biosynthesis [11]. However, cell death, induced by tetraconazole in this study, was found mainly dependent on apoptosis, which was demonstrated with mitochondrial impairment, ROS accumulation, DNA fragmentation, and condensed cell nuclei, while many other azoles were found to induce cell death via blocking glycolysis, calcium influx and membrane biosynthesis [58].

Mitochondrial impairment and oxidative stress following the elevation of ROS production are known to be deleterious, which are having the potential to start cell death signaling [59]. An increase in oxidative molecules, such as hydrogen peroxide, hydroxyl radical, and superoxide anion was detected by NBT and DCFDA assays in our study. Besides, our results demonstrated a dose-dependent increase in oxidation of cellular compartments which was supported by elevations in expressions of cytosolic (Sodl) and mitochondrial superoxide dismutases (Sod2), and also in glutathione peroxidase. Similarly, a recent study reported that tetraconazole-induced oxidative stress, which was shown by MDA levels, superoxide dismutase, and catalase activities, led to chromosomal aberrations accompanying cell death in Allium cepa[60]. However, we found a negative correlation between ROS levels (oxidative stress) and mitochondrial inner membrane potential indicating oxidative damage on a mitochondrial membrane (see Fig. 2 and Fig. 3F). Previous studies elucidated the disruptive effects of oxidative stress on mitochondrial membrane permeability and mitochondrial DNA damage [61-63].

There are several candidate genes, which are suggested to be responsible for apoptosis in $S$. pombe.The fission yeast genome encodes only one caspase, which is known as Pcal. It is believed that Pcal plays a dual role in cell death decisions [64]. Although in our previous study, we showed elevated Pcal mRNA levels after chemical stress [42], however, in this study, tetraconazole treatment did not cause alteration in $P c a l$ levels except $10 \mathrm{mg} / \mathrm{L}$, which can be accepted as an overdose for tetraconazole treatment. The precise roles of Pcal and its ortholog Ycal (in S. cerevisiae), which were suggested to be metacaspases, in regulated cell death, are still waiting to be enlightened [65]. Similarly, Aifl mRNA levels were not altered in any tetraconazole dose group in this study. In baker's and fission yeasts, involvement of Aifl in apoptosis activated by chemical stress and acidic $\mathrm{pH}$ was shown by a few articles [66-68]. But, in contrast, tetraconazole did not show a similar effect on Aifl transcription in this study. Finally, Cnxl, which was suggested to regulate ER stress-related proteotoxicity and apoptosis in S. pombe [53], was demonstrated to have a potential role in tetraconazole-induced cell death in our study. Transcriptional activation of $C n x l$ after tetraconazole treatment supports our hypothesis of its involvement in the fission yeast cell death signaling. However, some reports are suggesting that Cnxl is involved in both autophagy and apoptosis or manage crosstalk between them [69]. 


\section{CONCLUSION}

In conclusion, tetraconazole caused dose-dependent apoptotic cell death. Cytotoxicity was related to oxidative damage and disruption of mitochondria. This study, also, examined three $S$. pombe genes that were believed to positively regulate apoptosis, and, consequently, induce cell death. Moreover, this study warrants further study aiming at programmed (or regulated) cell death pathways, lipotoxicity, and autophagy, or, cellular aging using molecular genetics insights.

\section{ACKNOWLEDGEMENT}

This work was supported by Istanbul Yeni Yuzyil University. We specially thanks to Aysegul TopalSarikaya, Bedia Palabiyik for providing S. pombe cells, Sinem Tunçer Gurbanov and Emre Yoruk for consumables and chemicals.

\section{REFERENCES}

[1] Gavarkar, P. S., Adnaik, R. S., \& Mohite, S. K. (2013). An Overview of Azole Antifungals. International Journal of Pharmaceutical Sciences and Research, 4, 4083-4089.

[2] Templeton, I. E., Thummel, K. E., Kharasch, E. D., Kunze, K. L., Hoffer, C., Nelson, W. L., \& Isoherranen, N. (2008). Contribution of Itraconazole Metabolites to Inhibition of CYP3A4 In Vivo. Clinical Pharmacology \& Therapeutics, 83, 77-85.

[3] Vermeer, L. M. M., Isringhausen, C. D., Ogilvie, B. W., \& Buckley, D. B. (2016). Evaluation of Ketoconazole \& Its Alternative Clinical CYP3A4/5 Inhibitors as Inhibitors of Drug Transporters: The In Vitro Effects of Ketoconazole, Ritonavir, Clarithromycin, and Itraconazole on 13 Clinically-Relevant Drug Transporters. Drug Metabolism and Disposition, 44, 453-459.

[4] Shirasaka, Y., Sager, J. E., Lutz, J. D., Davis, C., \& Isoherranen, N. (2013). Inhibition of CYP2C19 and CYP3A4 by Omeprazole Metabolites and Their Contribution to Drug-Drug Interactions. Drug Metabolism and Disposition, 41, 1414-1424.

[5] Mishra, A., Malakar, A., Biswal, H. T., Barman, M. K., \& Krishnamoorthy, G. (2015). Interactions of a few azole derivatives with a transport protein: role of heteroatoms. Journal of Molecular Recognition, 28, 299305.

[6] Banerjee, K., Oulkar, D. P., Patil, S. H., Dasgupta, S., \& Adsule, P. G. (2008). Degradation kinetics and safety evaluation of tetraconazole and difenoconazole residues in grape. Pest Management Science, 64, 283 289.

[7] Tong, Z., Dong, X., Yang, S., Sun, M., Gao, T., Duan, J., \& Cao, H. (2019). Enantioselective effects of the chiral fungicide tetraconazole in wheat: Fungicidal activity and degradation behavior. Environmental Pollution, 247, 1-8.

[8] Carelli, A., Farina, G., Gozzo, F., Merlini, L., \& Kelly, S. L. (1992). Interaction of tetraconazole and its enantiomers with cytochrome P450 from Ustilago maydis. Pesticide Science, 35, 167-170.

[9] Emami, S., Tavangar, P., \& Keighobadi, M. (2017). An overview of azoles targeting sterol 14 $\alpha$-demethylase for antileishmanial therapy. European Journal of Medicinal Chemistry, 135, 241-259.

[10] Warrilow, A. G. S., Price, C. L., Parker, J. E., Rolley, N. J., Smyrniotis, C. J., Hughes, D. D., Thoss, V., Nes, W. D., Kelly, D. E., Holman, T. R., \& Kelly, S. L. (2016). Azole Antifungal Sensitivity of Sterol $14 \alpha-$ Demethylase (CYP51) and CYP5218 from Malassezia globosa. Scientific Reports, 6, 27690.

[11] Lv, Q., Yan, L., \& Jiang, Y. (2016). The synthesis, regulation, and functions of sterols in Candida albicans: Well-known but still lots to learn. Virulence, 7, 649-659.

[12] Office of Pesticide Programs, U. (2006). Pesticide fact sheet for tetraconazole. U.S. EPA [online], https://www.epa.gov/pesticides (Accessed April 4, 2019).

[13] Office of Pesticide Programs, U. (2007). Tetraconazole: Human-Health Risk Assessment for Proposed Uses on Soybean, Sugar Beet, Peanut, Pecan, and Turf. U.S. EPA [online], https://www.epa.gov/pesticides (Accessed April 4, 2019).

[14] Authority, A. P. and V. M. (2005). Evaluation of the new active Tetraconazole in the product Domark 40ME Fungicide, [online] http://fluoridealert.org/wpcontent/pesticides/tetraconazole.2005.report.australia.pdf (Accessed April 5, 2019).

[15] Daniel, S. L., Hartman, G. L., Wagner, E. D., \& Plewa, M. J. (2007). Mammalian Cell Cytotoxicity Analysis of Soybean Rust Fungicides. Bulletin of Environmental Contamination and Toxicology, 78, 474-478. 
[16] El-Sherief, H. A. M., Youssif, B. G. M., Bukhari, S. N. A., Abdel-Aziz, M., \& Abdel-Rahman, H. M. (2018). Novel 1,2,4-triazole derivatives as potential anticancer agents: Design, synthesis, molecular docking and mechanistic studies. Bioorganic Chemistry, 76, 314-325.

[17] Ahmad, K., Khan, M. K. A., Baig, M. H., Imran, M., \& Gupta, G. K. (2018). Role of Azoles in Cancer Prevention and Treatment: Present and Future Perspectives. Anti-Cancer Agents in Medicinal Chemistry, 18, 46-56.

[18] Filho, R. I., Gonzaga, D. T. G., Demaria, T. M., Leandro, J. G. B., Costa, D. C. S., Ferreira, V. F., SolaPenna, M., de C. da Silva, F., \& Zancan, P. (2018). A Novel Triazole Derivative Drug Presenting In Vitro and In Vivo Anticancer Properties. Current Topics in Medicinal Chemistry, 18, 1483-1493.

[19] Sidrim, J. J. C., de Maria, G. L. \& Paiva, M. D. et al. (2021). Azole-Resilient Biofilms and Non-wild Type C. Albicans Among Candida Species Isolated from Agricultural Soils Cultivated with Azole Fungicides: an Environmental Issue?. Microbial Ecology. https://doi.org/10.1007/s00248-021-01694-y

[20] Demuyser L \& Van Dijck P. (2019) Can Saccharomyces cerevisiae keep up as a model system in fungal azole susceptibility research? Drug Resistance Updates. 42, 22-34.

[21] Martins, D., Nguyen, D. \& English, A.M. (2019) Ctt1 catalase activity potentiates anti fungalazoles in the emerging opportunistic pathogen Saccharomyces cerevisiae. Scientific Reports, 9, 9185.

[22] Hagan, I. M., Grallert, A., \& Simanis, V. (2016). Analysis of the Schizosaccharomyces pombe Cell Cycle. Cold Spring Harbor Protocols, 2016, pdb.top082800.

[23] Koyama, M., Nagakura, W., Tanaka, H., Kujirai, T., Chikashige, Y., Haraguchi, T., Hiraoka, Y., \& Kurumizaka, H. (2017). In vitro reconstitution and biochemical analyses of the Schizosaccharomyces pombe nucleosome. Biochemical and Biophysical Research Communications, 482, 896-901.

[24] Lin, S. J., \& Austriaco, N. (2014). Aging and cell death in the other yeasts, Schizosaccharomyces pombe and Candida albicans. FEMS Yeast Research, 14, 119-135.

[25] Agus, H. H., Sengoz, C. O., \& Yilmaz, S. (2019). Oxidative stress-mediated apoptotic cell death induced by camphor in sod1-deficient Schizosaccharomyces pombe. Toxicology Research, 8, 216-226.

[26] Madeo, F., Herker, E., Wissing, S., Jungwirth, H., Eisenberg, T., \& Fröhlich, K.-U. (2004). Apoptosis in yeast. Current Opinion in Microbiology, 7, 655-660.

[27] Sajiki, K., Hatanaka, M., Nakamura, T., Takeda, K., Shimanuki, M., Yoshida, T., Hanyu, Y., Hayashi, T., Nakaseko, Y., \& Yanagida, M. (2009). Genetic control of cellular quiescence in S. pombe. Journal of Cell Science, 122, 1418-29.

[28] Lock, A., Rutherford, K., Harris, M. A., \& Wood, V. (2018). PomBase: The Scientific Resource for Fission Yeast. Methods in Molecular Biology, 1757, 49-68.

[29] Liu, M., Huang, Y., Wen, H., \& Qiu, G. (2015). Comparing Cell Toxicity of Schizosaccharomyces pombe Exposure to Airborne PM2.5 from Beijing and Inert Particle SiO2. Huan Jing Ke Xue= Huanjing Kexue, 36, 3943-51.

[30] Olayanju, B., Hampsey, J. J., \& Hampsey, M. (2015). Genetic analysis of the Warburg effect in yeast. Advances in Biological Regulation, 57, 185-192.

[31] Carmona-Gutierrez, D., Reisenbichler, A., Heimbucher, P., Bauer, M. A., Braun, R. J., Ruckenstuhl, C., Büttner, S., Eisenberg, T., Rockenfeller, P., Fröhlich, K.-U., Kroemer, G., \& Madeo, F. (2011). Ceramide triggers metacaspase-independent mitochondrial cell death in yeast. Cell Cycle, 10, 3973-3978.

[32] Natter, K., \& Kohlwein, S. D. (2013). Yeast and cancer cells - common principles in lipid metabolism. Biochimica et Biophysica Acta, 1831, 314-326.

[33] Villahermosa, D., Knapp, K., \& Fleck, O. (2017). A mutated dph3 gene causes sensitivity of Schizosaccharomyces pombe cells to cytotoxic agents. Current Genetics, 63, 1081-1091.

[34] Castro, C., Flores, D.-L., Cervantes-Vásquez, D., Vargas-Viveros, E., Gutiérrez-López, E., \& Muñoz-Muñoz, F. (2019). An agent-based model of the fission yeast cell cycle. Current Genetics, 65, 193-200.

[35] Vishwanatha, A., \& D'Souza, C. J. M. (2017). Multifaceted effects of antimetabolite and anticancer drug, 2deoxyglucose on eukaryotic cancer models budding and fission yeast. IUBMB Life, 69, 137-147.

[36] Carmona-Gutierrez, D., Bauer, M. A., Zimmermann, A., Aguilera, A., Austriaco, N. et al. (2018). Guidelines and recommendations on yeast cell death nomenclature. Microbial Cell, 5, 4-31.

[37] Emami, P \& Ueno, M. (2021). 3,3'-Diindolylmethane induces apoptosis and autophagy in fission yeast. BioRxiv. (preprint). DOI: https://doi.org/10.1101/2021.08.05.455326

[38] Falcone, C. \& Mazzoni, C. (2016). External and internal triggers of cell death in yeast. Cellular and Molecular Life Sciences, 73, 2237-2250. 
[39] Du, L., Yu, Y., Chen, J., Liu, Y., Xia, Y., Chen, Q., \& Liu, X. (2007). Arsenic induces caspase-and mitochondria-mediated apoptosis in Saccharomyces cerevisiae. FEMS Yeast Research, 7, 860-865.

[40] Chazotte, B. (2011). Labeling nuclear DNA using DAPI. Cold Spring Harbor Protocols, 2011, pdb.prot5556.

[41] Pajaniradje, S., Mohankumar, K., Pamidimukkala, R., Subramanian, S., \& Rajagopalan, R. (2014). Antiproliferative and apoptotic effects of sesbania grandiflora leaves in human cancer cells. BioMed Research International, 2014, 474953.

[42] Agus, H. H., Kok, G., Derinoz, E., Oncel, D., \& Yilmaz, S. (2020). Involvement of Pca1 in ROS-mediated apoptotic cell death induced by alpha-thujone in the fission yeast (Schizosaccharomyces pombe). FEMS Yeast Research, 20, foaa022.

[43] Azad, G. K., Singh, V., Mandal, P., Singh, P., Golla, U., Baranwal, S., Chauhan, S., \& Tomar, R. S. (2014). Ebselen induces reactive oxygen species (ROS)-mediated cytotoxicity in Saccharomyces cerevisiae with inhibition of glutamate dehydrogenase being a target. FEBS Open Bio.,4, 77-89.

[44] Kwolek-Mirek, M., \& Zadrag-Tecza, R. (2014). Comparison of methods used for assessing the viability and vitality of yeast cells. FEMS Yeast Research, 14, 1068-1079.

[45] Yörük, E. (2018). Tetraconazole Leads To Alterations In Fusarium Graminearum At Different Molecular Levels. Applied Ecology and Environmental Research, 16, 6155-6167.

[46] Salucci, S., Burattini, S., Falcieri, E., \& Gobbi, P. (2015). Three-dimensional apoptotic nuclear behavior analyzed by means of Field Emission in Lens Scanning Electron Microscope. European Journal of Histochemistry: EJH, 59, 2539.

[47] Mutoh, N., Kitajima, S., \& Ichihara, S. (2011). Apoptotic Cell Death in the Fission Yeast Schizosaccharomyces pombe Induced by Valproic Acid and Its Extreme Susceptibility to pH Change. Bioscience, Biotechnology, and Biochemistry, 75, 1113-1118.

[48] Muñoz, M., Cedeño, R., Rodríguez, J., Van Der Knaap, W. P. W., Mialhe, E., \& Bachère, E. (2000). Measurement of reactive oxygen intermediate production in haemocytes of the penaeid shrimp, Penaeus vannamei. Aquaculture, 191, 89-107.

[49] Zhu, S., Luo, F., Zhu, B., \& Wang, G.-X. (2017). Toxicological effects of graphene oxide on Saccharomyces cerevisiae. Toxicology Research, 6, 535-543.

[50] Schnabel, D., Salas-Vidal, E., Narváez, V., del Rayo Sánchez-Carbente, M., Hernández-García, D., Cuervo, R., \& Covarrubias, L. (2006). Expression and regulation of antioxidant enzymes in the developing limb support a function of ROS in interdigital cell death. Developmental Biology, 291, 291-299.

[51] Barroso, G., Taylor, S., Morshedi, M., Manzur, F., Gaviño, F., \& Oehninger, S. (2006). Mitochondrial membrane potential integrity and plasma membrane translocation of phosphatidylserine as early apoptotic markers: a comparison of two different sperm subpopulations. Fertility and Sterility, 85, 149-154.

[52] Baracca, A., Sgarbi, G., Solaini, G., \& Lenaz, G. (2003). Rhodamine 123 as a probe of mitochondrial membrane potential: evaluation of proton flux through $\mathrm{F}(0)$ during ATP synthesis. Biochimica et Biophysica Acta, 1606, 137-146.

[53] Guérin, R., Arseneault, G., Dumont, S., \& Rokeach, L. A. (2008). Calnexin is involved in apoptosis induced by endoplasmic reticulum stress in the fission yeast. Molecular Biology of the Cell, 19, 4404-20.

[54] Low, C. P., \& Yang, H. (2008). Programmed cell death in fission yeast Schizosaccharomyces pombe. Biochimica et Biophysica Acta (BBA) - Molecular Cell Research, 1783, 1335-1349.

[55] Lin, S. J., \& Austriaco, N. (2014). Aging and cell death in the other yeasts, Schizosaccharomyces pombe and Candida albicans. FEMS Yeast Research, 14, 119-135.

[56] Sevrioukova, I. F. (2011). Apoptosis-inducing factor: structure, function, and redox regulation. Antioxidants \& Redox Signaling, 14, 2545-2579.

[57] Azzopardi, M., Farrugia, G., \& Balzan, R. (2017). Cell-cycle involvement in autophagy and apoptosis in yeast. Mechanisms of Ageing and Development, 161, 211-224.

[58] Yardımcı, B. K. (2020). Imidazole Antifungals: A Review of Their Action Mechanisms on Cancerous Cells. International Journal of Secondary Metabolite, 2020, 139-159.

[59] Zhang, C., Lai, S. H., Yang, H. H., Xing, D. G., Zeng, C. C., Tang, B., Wan, D., \& Liu, Y. J. (2017). Photoinduced ROS regulation of apoptosis and mechanism studies of iridium(iii) complex against SGC-7901 cells. RSC Advances, 7, 17752-17762.

[60] Macar, O. (2021). Multiple toxic effects of tetraconazole in Allium cepa L. meristematic cells. Environmental Science and Pollution Research, 28, 10092-10099. 
[61] Wang, J., Luo, B., Li, X., Lu, W., Yang, J., Hu, Y., Huang, P., \& Wen, S. (2017). Inhibition of cancer growth in vitro and in vivo by a novel ROS-modulating agent with ability to eliminate stem-like cancer cells. Cell Death \& Disease, 8, e2887.

[62] Bhat, A. H., Dar, K. B., Anees, S., Zargar, M. A., Masood, A., Sofi, M. A., \& Ganie, S. A. (2015). Oxidative stress, mitochondrial dysfunction and neurodegenerative diseases; a mechanistic insight. Biomedicine \& Pharmacotherapy, 74, 101-110.

[63] Li, J., Liu, X., Zhang, Y., Tian, F., Zhao, G., Yu, Q., Jiang, F., \& Liu, Y. (2012). Toxicity of nano zinc oxide to mitochondria. Toxicology Research, 1, 137.

[64] Lim, H. W., Kim, S. J., Park, E. H., \& Lim, C. J. (2007). Overexpression of a metacaspase gene stimulates cell growth and stress response in Schizosaccharomyces pombe. Canadian Journal of Microbiology, 53, 1016-1023.

[65] Chaves, S. R., Rego, A., Martins, V. M., Santos-Pereira, C., Sousa, M. J., \& Côrte-Real, M. (2021). Regulation of Cell Death Induced by Acetic Acid in Yeasts. Frontiers in Cell and Developmental Biology, 9, 642375 .

[66] Amigoni, L., Frigerio, G., Martegani, E., \& Colombo, S. (2016). Involvement of Aif1 in apoptosis triggered by lack of Hxk2 in the yeast Saccharomyces cerevisiae. FEMS Yeast Research, 16, fow016.

[67] Muzaffar, S., \& Chattoo, B. B. (2017). Apoptosis-inducing factor (Aif1) mediates anacardic acid-induced apoptosis in Saccharomyces cerevisiae. Apoptosis, 22, 463-474.

[68] Ăguş, H. H., Yilmaz, S., \& Şengöz, C. O. (2019). Crosstalk between autophagy and apoptosis induced by camphor in Schizosaccharomyces pombe. Turkish Journal of Biology, 10.3906/biy-1908-11.

[69] Núñez, A., Dulude, D., Jbel, M., \& Rokeach, L. A. (2015). Calnexin is essential for survival under nitrogen starvation and stationary phase in Schizosaccharomyces pombe. PloS One, 10, e0121059. 